\title{
Fuel Oil Distribution in Regional Level in Indonesia
}

\author{
Arnelis Jessika ${ }^{1}$, Bani Immanuel Ginting ${ }^{2}$ \\ \{arnelisjessika29@gmail.com ${ }^{1}$ \} \\ Master of Law Study Program of University of Lampung ${ }^{1,2}$
}

\begin{abstract}
One of the priority agenda of Nawa Cita Joko Widodo-Jusuf Kalla is the distribution of development and economics in all regions of Indonesia. An implementation of it would be the improvement of public facilities in remote areas. It causes fuel oil (BBM) needs to continue to increase. As a consequence, the country needs an equitable distribution of fuel; however, there is often an inequality of oil fuel distribution, as what occurred in Bunga Mayang district of North Lampung. The local community should travel approximately $40 \mathrm{~km}$ to reach the nearest gas station; Negararatu, and often the gas station has run out of fuel oil. Some people who carried oil transportation from the gas station to Bunga Mayang were arrested and sentenced to 8 (eight) months in prison per the ruling of the city-state court No: 66/Pid. Sus/2017/PN. Kbu although they have made it easy for people to get fuel oil. This research examines that Law No. 22 of 2001 on oil and Gas has not been made clear about the granting of permits to business activities in remote areas. The requirements to obtain existing permits are quite challenging to reach by communities with the lower middle class. Other laws and regulations are also deemed to have not matched the situation in the remote areas so that 3 (three) fundamental values of the law, namely justice, legal certainty, and benefit for the community are yet to be achieved.
\end{abstract}

Keywords: Distribution; fuel oil; remote areas

\section{Introduction}

\subsection{Research Significance}

After officially became president and Vice President of the Republic of Indonesia and inaugurated on 20 October 2014, Joko Widodo and Jusuf Kalla designed nine priority agenda called Nawa Cita. The Program is made to demonstrate the priorities of the changing roads to Indonesia, which are politically sovereign, independent in the field of economics, and personality in the field of culture. Building Indonesia from the periphery by strengthening areas and villages within the framework of the unitary state is one of the implementations of Article 33 on the National Economy and Social Welfare of the Constitution of the Republic of Indonesia 1945. The Constitution 1945 is the highest legal basis in Indonesia per Law No. 10 of 2004 on the establishment of statutory regulations.

Article 33 briefly explain that the state controls all branches of production such as Earth, water, and natural wealth, it is then compiled based on the principle of family and use for the prosperity of the people. Also, this is then implemented in economic democracy with several principles that are the principle of togetherness, fairness, sustainable, environmentally sound, 
independence and by maintaining the balance of progress and economic unity of the nation, and all the perpetrations are governed in law.

The purpose and objectives of the distribution of development and economics and article 33 UUD 1945 is an element of equality in all parts of Indonesia from the big city to remote areas in the field of natural wealth management. Natural wealth is controlled by the state but must be managed well and sustainably for the prosperity of the people as a manifestation of national ideals and objectives. Article 33 UUD 1945 is the basis for the establishment of the Law of the Republic of Indonesia No. 22 of 2001 on Oil and Gas.

However, in the practice of law enforcement of the Republic of Indonesia, number 22 of 2001 on Oil and Gas is still found inconsistency with circumstances in society. As an example, the distribution of oil fuel that occurred in Bunga Mayang North Lampung Regency, which is a remote area and quite challenging for the community to get fuel oil. Seeing the situation, several people took an opportunity to distribute it illegally. As a result, they were sentenced to prison 8 (eight) months under the decision of the District Court of Kotabumi No: 66/Pid. Sus/2017/PN. Kbu. There is a discrepancy between the law written with the reality of the community, which proves that the law of the Republic of Indonesia number 22 of 2001 on oil and Gas is considered less effective and needs revision or renewal. Notably, in the field of granting distribution permits in remote areas to fit the circumstances and situation as well as reach the welfare of the community.

The definition of "renewal" (Pembaruan) or "renewal" (Pembaharuan) in the General Indonesian dictionary by W.J.S. Poerwadarminta is interpreted as an act or way of updating. "Updating" has three understandings:

1. Fix to be new;

2. Repeat/ Start again;

3. Replace with new ones

Linking the three understandings above with the criminal law as the subject of renewal, the most appropriate sense to use for the renewal of criminal law (criminal law politics) is the third sense, which is "replacing with new ones". Based on the background above, it encourages authors to research "Fuel Oil Distribution In Regional Level In Indonesia."

\subsection{Formulation of Questions}

Based on the background, the formulation of the research is to corroborate the objective of achieving the law enforcement against the distribution of oil fuels in remote areas based on Act No. 22 of 2001 on Oil and Gas and other regulations.

\subsection{Theory and Related Work}

Distribution is the delivery of goods and services to several retailers, distributors of something that shares with some people or several places. Fuel oil is a fuel derived and/or processed from petroleum. Regional is an area of cities, districts, and other regions within a country; remote areas are a place or area that is difficult to reach for several reasons, namely geography (forest, mountains, islands, swamp), transportation, social and economic. 


\section{Research Method}

The research method used is empirical. The research uses empirical studies is to examine the prevailing laws and regulations that are then associated with the legal facts that occur in the community. The data used in this study are primary data, sourced from statutory regulations and court decisions, and secondary data, sourced from books, legal dictionaries, and legal journals. These data are processed using descriptive and analytical-qualitative methods.

\section{Results and Discussion}

\subsection{The decision of the District Court of Kotabumi No.: 66/Pid. Sus/2017/PN. Kbu}

The verdict of the Kotabumi Court number: 66/Pid. Sus/2017/PN. KBU contains a trial of 2 (two) defendants, MUHAMMAD RIFAI and MUHAMMAD ANDI SAPUTRA, who have been proven to have committed a criminal offense "participate in the carriage of subsidized fuel without legitimate permission" and sentenced to prison respectively for 8 (eight) months and the penalty of fines of Rp. 40 million,-(forty million rupiah) provided that if the fine is not payable, it is replaced by imprisonment for 3 (three) months.

The example of the case explains that the transportation of oil fuel that occurs in Bunga Mayang North Lampung Regency, close to PTPN VII Bunga Mayang sugar Factory, is a fairly remote place and does not have a Gas station (filling stations/Public Fuel). Under Article 33, Paragraph (3) of Law No. 22 of 2001, oil and gas business activities cannot be carried out adjacent to the factory except with the permission of government agencies. The nearest gas station is about 40 kilometers from the Bunga Mayang region, but that particular gas station often does not have the supply of oil or empty gasoline. This situation is considered an opportunity by several persons to distribute it illegally. It helps local people to meet the needs of everyday life that are supported by fuel oil. The wage for the carrier is also very cheap, which is only 350-450 rupiah per liter. However, the perpetrator of the criminal offense remains convicted by the Kotabumi District Court, which is 8 (eight) months in jail.

\subsection{Distribution of Oil Fuels in Remote Areas}

Consumption of domestic oil fuels continues to rise to promote economic growth and equitable. However, unfortunately, it is not balanced with oil production. If such circumstances are left continuously, then Indonesia will continue to depend on the supply of imported oil. Increased consumption of fuel oil is a natural thing to support the growth and equitable of the economy; it becomes unnatural when the consumption of oil is not efficient because it triggered cheap fuel prices subsidized by the government. The distribution of fuel oil is also one of the problems that Indonesia has as oil fuel is not evenly distributed in some remote areas. Therefore, it is necessary to set up legislation to regulate and control the distribution of oil and gas. Based on the Act of the Republic of Indonesia number 22 of 2001 on Oil and Gas and other derivative regulations, a body is formed to make arrangements and supervision on the provision and distribution of Oil and Gas Fuels are BPH Migas (Downstream Oil and Gas Regulatory Bodies).

Based on the law of the Republic of Indonesia Number 8 of 1971 about the State Oil and Gas Mining Company (PERTAMINA), it regulates that the oil and gas industry should only 
be undertaken by the State companies solely in this regard Pertamina. In Indonesia itself there are three types of fuel oil established by the government based on the Regulation of the President of the Republic of Indonesia Number 191 of 2014 on the provision, distribution and retail price of petroleum fuel, namely the following:

Article 1

1. Certain types of fuel oils are referred to as Certain Fuel are fuels derived and/or processed from petroleum and/or processed from petroleum which has been mixed with biofuels as other fuels with the type, standard and quality (specification), price, volume and specific consumer and given subsidies.

2. Special Oil Fuel Assignment Type is referred to as Special Types of Fuel Assignment are fuel derived from and/or processed from petroleum and/or fuel derived and/or processed from petroleum that has been mixed with biofuel as another fuel of a particular type, standard and quality (specification) distributed in the assignment area and not subsidized.

3. Type of general fuel oil which is referred to as type of General Fuel is fuel derived and/or processed from petroleum and/or fuel derived and/or processed from petroleum which has been mixed with vegetable fuel (biofuel) As other fuels with certain types, standards and quality (specifications) and is not subsidized.

In other words, fuel oil in Indonesia is classified into subsidized and unsubsidized fuel oil. Subsidized petroleum fuel is the fuel that has received discounted prices or financial assistance from the Government to increase the purchasing power of consumers in the lower middle circles, for example, are Solar and Kerosene. Non-subsidized fuel oil is the fuel of oil that does not get discounted or government financial assistance due to the price of non-subsidized petroleum fuel following the price dynamics of the crude oil and the rupiah exchange rate in the global market; Premium, Pertamax, Pertamax Turbo, Pertalite, Pertamina Dex, and Dexlite.

\subsection{Distribution of Oil Fuels in Remote Areas}

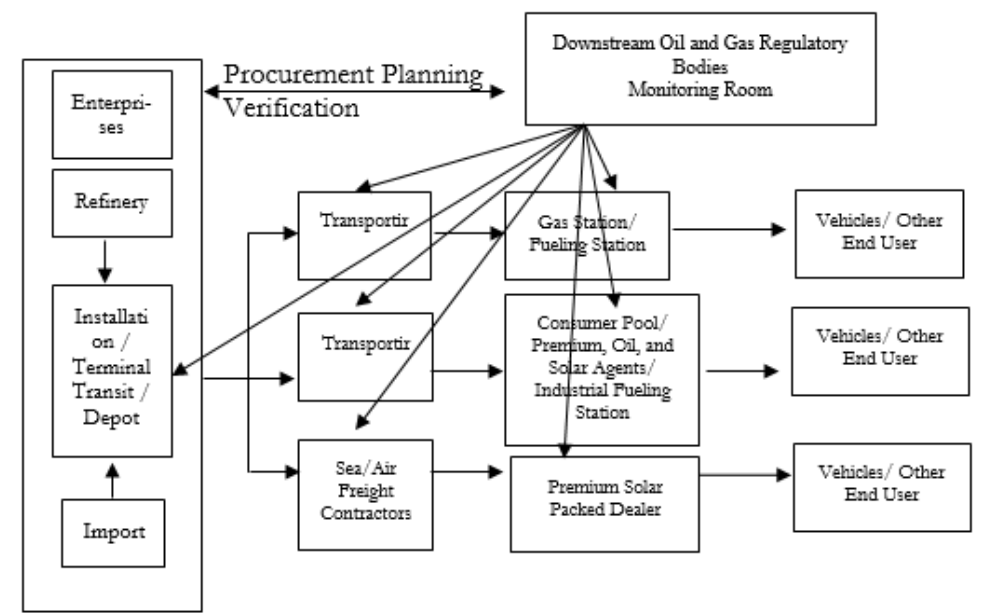

Fig.1 Petroleum Distribution Flows

According to Soekartawi, the meaning of distribution is the activity of channeling or delivering goods and services to the consumer. The distribution of oil fuels that occur in 
remote areas including downstream business activities as happened in the case in Bunga Mayang North Lampung District is an indirect distribution where PT. Pertamina, as the primary distributor, Distribute fuel oil to the area through a third party of individuals. The distribution activities of subsidized and non-subsidized oil fuels must also be supplemented by legal business license issued by the Minister of Energy and Mineral resources delegated to BPH Migas under Act No. 22 of 2001 on oil and Gas and other derivative regulations.

Article 23 explains that the new business entity can carry out downstream business activities after receiving a business license from the government, as for the business license of management business license, transportation business license, storage business license, and commercial business license, and Any business entity may have more than 1 (one) business license as long as it does not contradict the prevailing laws and regulations.

Article 29 explains that in the event of a shortage of oil fuel in remote areas, the transportation, storage, and other facilities can be utilized with other parties which are then governed by the governing body and do not ignore the aspects of technical and economical.

Article 30 explains that government regulations govern regulations such as processing, transport, storage, and commerce in article 23 to article 29.

According to the above articles, it is clear that downstream business activities which include processing, transporting, storing, and trading both for subsidized and non-subsidized fuels in remote areas must have permits which then the permit is further stipulated in the Government Regulation of the Republic of Indonesia Number 36 of 2004 about Downstream Oil and Gas Business Activities.

Article 8 paragraph (1) letter A explains that the business entity that has had a business permit from the Minister should guarantee the availability and distribution of fuel oil in the entire territory of the Republic of Indonesia that has been established Government.

Article 75 explains that the policy stipulated by ministers in remote areas is based on the consideration of location, readiness of market formation and the strategic value of the region concerned, by not ignoring the consideration of the governing body.

Article 76 explains that the fuel oil transmitted to the remote area is regulated and stipulated by the governing body which the business entity can cooperate with the local-owned enterprises, cooperatives, small businesses and national enterprises that have been has a distribution network in remote areas without ignoring the technical and economic aspects, as for the remote areas are obliged to receive the distribution of gasoline-type oil, diesel oil and kerosene tailored to the needs of the region concerned.

Article 8 paragraph (1) letter A, article 75, and article 76 regulation of the Government of Republic of Indonesia Number 36 of 2004 about downstream Oil and Gas business activities explained that the distribution of oil fuel conducted by every business entity that has been granted permission from BPH Migas and has been established by the government should spread evenly to remote areas. It is under Joko Widodo-Jusuf Kalla's program, Nawa Cita, on the equitable development and economy. However, in particular communities, there are still areas that have difficulty getting fuel oil.

\subsection{Objectives on Achieving Legal Enforcement}

Given the business license that has been governed by Act No. 22 of 2001, the Government Regulation of Republic of Indonesia No. 36 of 2004 and other regulations, it is still considered very difficult to obtain the business license. For some business entities with competent human resources in reachable areas, it is not too difficult to obtain such permits. However, other circumstances occur in remote areas that have limited education on human 
resources. The lack of understanding of existing regulations and considerations to get the business license is very complicated, coupled with the economic limitations that make them perform various ways to meet daily needs. Not to mention, BPH Migas is headquartered in South Jakarta, which makes it difficult for people in remote areas to be able to obtain these permits. Legal facts where oil fuel carriers in the form of premium and diesel are still sentenced to 8 (eight) months jail in Bunga Mayang, North Lampung Regency is not in accordance with Joko Widodo-Jusuf Kalla's program, Nawa Cita, about equalization. They helped the distribution in the area. Thus, it is also considered not in accordance with the real legal purpose of realizing justice as expressed by the Roman philosophers Aristotle and Hans Kalsen with his theory of righteousness.

In the framework of the thought of Aristotle, Eudaimonia (the highest goodness that is the goal of all Politika) is only possibly embodied in the Agathon Kai Ariston (the highest good for any and every one), which for Aristotle is (logos) manifested through human ethical conduct. That noble deed could not be ignored, for Aristotle, the Eudaimonia which also included justice (as he had earlier pointed out in his book Nomoi) must be enforced nomothetical, which means that justice should be enforced by law. Alternatively, in the language of our day: justice must be enforced by law. Justice is indeed an essential principle in Aristotle's teachings because it is relevant to the reciprocal relationship between humans living together with the policy to be able to fulfill the need for civilization. The social life of a fellow man becomes impossible if it is not supported by justice.

Kalsen relied on the rationality of the norm of justice in one of the most ancient teachings about what justice was from a legal expert, Domitius Ulpainus (Romans, 170-223), who expressed his formulation of justice as recorded in Digest Iustiniani, Justice is a steadfast will and the syndicate to give to whoever what is the right. The necessity of the law is as follows: Live with respect, do not hurt others, and give to anyone what is right. Kelsen accepted the doctrine of Ulapinus as a rational norm of justice, which was applied in inter-human relations as a "glorious rule."

The modern legal thought posed by Gustav Radbruch seeks to combine the three classical views (philosophical, normative and empirical) into a single approach which is then known as the Three Legal Principles that include: Justice (Philosophy), Legal Certainty (Juridical) and the Benefit of the Society (Sociological). Furthermore, Radbruch teaches the use of the fundamental priorities of the three principles, where the priority always falls on justice, then benefits, and lastly legal certainty.

Based on the theory of justice expressed by Aristotle and Hans Kalsen, the theory of the The Three Legal Principle of the law of justice, legal certainty, and the benefit of society as stated by Gustav Radbruch above, suggested that the regulations Legislation made by the Government should be enforced based on the essential purpose of the realization of justice, legal certainty, and benefit to society. However, to make it happen is not easy; it should be supported by several factors that influence the enforcement of the law itself, namely:

1. The legal factor itself.

2. Law enforcement factors, the parties who form or apply the law.

3. Factors which support the enforcement of the law.

4. Community factors, i.e., the environment in which the law applies or applied.

5. Cultural factors, namely; the work, copyright, dan essence that is based on the karsa (wish/intention of a human) in life.

The legal factor itself affects the enforcement of laws due to nonadherence to the enactment of laws, in particular, the absence of implementing regulations that are much needed to apply legislation. Besides, the uncertain meaning of words in the law results in the 
implications of its interpretation and application. The law enforcement factor has some disadvantages that are limited ability to play his role and with whom he interacts, lack of desire to think of the future of this country due to limited knowledge, closed attitude to changes, and attitudes that are more concerned with personal interest rather than the interests of the society.

The insufficient factors of facilities can inhibit the enforcement of the law because it will not be possible that law enforcement can carry out their duties without adequate facilities. Factors of society also become one that affects the enforcement of the law, if the community itself has an open mind and has an excellent educational background, it will be easier for the law to be applied. People who are already aware of the law will be less likely to commit violations and criminal acts. Cultural factors are influential because some regions in Indonesia are still using customary law, which is the Law of Customs; this law is considered more effective to cause a deterrent effect than the written law. For example, in Aceh province, adultery performed by couples who do not have a bond of marriage will be given a penalty of a whip in front of the crowd.

These factors also affect the case of the law that occurred in Bunga Mayang North Lampung District about the polemic of distribution of oil fuels in remote areas. It is one of many similar cases that occurred in Lampung province. The legal certainty has been reached as the settlement of the case is deemed to be under Act No. 22 of 2001. It is challenging for the judge to accommodate The Three Principles: justice, benefit, and legal certainty in one verdict. At least the judge must choose one of these principles; however, it would be sensible to put justice and benefit first. Also, for the community, the purpose of the law is not achieved because it is considered unfair and not beneficial if the perpetrators of the criminal, who help the surrounding communities who are struggling to get fuel oil, were sentenced to eight months imprisonment.

This situation is because the area of Bunga Mayang is located near the sugar factory PTPN VII Bunga Mayang which is in accordance with article 33 paragraph (3) of the Law of the Republic of Indonesia Number 22 of 2001 that in a location near any factory should not be established Gas station with the purpose of minimising the government's subsidized oil fuel to not be misused for industrial purposes. The nearest public refueling station (Gas stations) is 40 kilometers away from the Bunga Mayang region, not to mention that the Gas station is often out-of-stock. These circumstances should be taken into account by the government to improve the prevailing laws and regulations. The legal factor is the most influential in the enforcement of the law.

Sometimes the laws made by legislative agencies lead to the obscurity of the words in the law that lead to confusion in the interpretation and application. Because the law is often made not following the circumstances of the community, therefore, Act No. 22 of 2001 about Oil and Gas needs to be revised, especially in the rules regarding the implementation of distribution in remote areas. It is easier to change the legislation than to change the society itself because the rules are made for the public order. Thus, the regulation should be made following the facts and conditions that exist in the community in order to achieve the fundamental purpose of the law.

\section{Conclusions}

\subsection{Conclusion}


Based on the research and discussions above, it can be concluded that the agenda priorities by Joko Widodo-Jusuf Kalla, Nawa Cita, about the equitable development and economics that led to the increase in the need for oil fuel results in less prevailing laws and regulations. It can be seen from the legal fact based on the decree of the Kotabumi District Court number: 66/Pid. Sus/2017/PN. Kbu as one of the applications of Act No. 22 of 2001 on Oil and Gas which, in which the distribution of oil fuels was slightly curtailed by the difficult permits obtained. Both subsidized and nonsubsidized oil fuels must still obtain permission from BPH Migas. Law, Government Regulation, Presidential Regulation, and Ministerial Regulation also explain that the permit of business activities upstream and downstream oil and gas must be obtained from the permission of the Minister of ESDM delegated to BPH Migas based in Jakarta South. It is not possible that these permits are easily reachable by people living in remote areas where they need fuel oil materials to meet the needs of everyday life while fuel oil distributors in the area are difficult to access.

Moreover, some people who tried to help the distribution of oil fuel in the remote area were sentenced. This fact raises the assumption that the enforcement of Act No. 22 of 2001 about Oil and Gas does not reach justice and benefit to remote areas, therefore, it is necessary to make revisions to the law, especially in the licensing of the distribution in remote areas.

\subsection{Recommendation}

Based on the above conclusions, the suggestions provided are:

1. The government, in this case, is the legislature as a lawmaker deemed necessary to revise Act No. 22 of 2001 about Oil and Natural Gas, in particular, to simplify the rules of granting distribution permits of petroleum in remote areas. So that the government's presence and the legal purposes of justice, legal certainty, and benefits can all be felt by Indonesian.

2. To all policymakers and authorities in order to relentlessly build governance that is clean, effective, democratic, and trustworthy by prioritizing efforts to restore public trust. It is to realize Indonesia, which is free from corruption, full of dignity, and trustful.

\section{References}

[1] Ali, Zainuddin. (2018). Metode Penelitian Hukum. Jakarta: Sinar Grafika.

[2] Djamali, R. Abdoel. (2007). Pengantar Hukum Indonesia. Jakarta: PT. Raja Grafindo Persada.

[3] Kusumohamidjojo, Budiono. (2017). Teori Hukum-Dilema antara Hukum dan Kekuasaaan. Bandung: Yrama Widya.

[4] Lamintang, P.A.F. (2013). Dasar-Dasar Hukum Pidana Indonesia. Bandung: PT. Citra Aditya Bakti.

[5] Lubiantara, Benny. (2017). Pradigma Baru Pengelolaan Sektor Hulu Migas dan Ketahanan Enegri. Jakarta: PT. Gramedia.

[6] Maroni. (2016). Pengantar Politik Hukum Pidana. Lampung: CV. Anugrah Utama Raharja.

[7] Rifai, Ahmad. (2014). Penemuan Hukum Oleh Hakim dalam Prespektif Hukum Progresif. Jakarta: Sinar Grafika.

[8] Rusianto, Agus. (2016). Tindak Pidana \& Pertanggungjawaban Pidana. Jakarta: Prenadamedia Group. 
[9] Salman, Otje. (2012). Filsafat Hukum-Perkembangan dan Dinamika Masalah. Bandung: PT. Refika Aditama.

[10] Soekarno, Seorjono. Faktor-Faktor yang Mempengaruhi Penegakkan Hukum. Jakarta: PT. Raja Grafindo Persada.

[11] Sutedi. (2012). Hukum Pertambangan. Jakarta: Sinar Grafika.

[12] Certified English translation of the 1945 Constitution of the Republic of Indonesia. First adopted August 18, 1945 - superseded 1949-1959 - restored 1959. Consolidated: as amended by the First Amendment (October 19, 1999), the Second Amendment (August 18, 2000), the Third Amendment (November 9, 2001) and the Fourth Amendment (August 11, 2002)

[13] Act Number 22 of 2001 regarding Petroleum and Gas.

[14] Act Number 8 of 1971 regarding the State Oil and Gas Mining Company

[15] Government Regulation of the Republic of Indonesia Number 36 of 2004 regarding Downstream Oil and Gas Business Activities.

[16] Government Regulation number. 30 of 2009 regarding the amendment to Government Regulation number 36 of 2004 about downstream oil and Gas business activities

[17] Presidential Regulation Number191 of 2014 regarding Supply, Distribution, and Retail price of Petroleum Fuel.

[18] Regulation of the Minister of Energy and Mineral Resources Number 0007 of 2005 regarding terms and guidelines for implementation of business license in downstream oil and Gas business activities

[19] Regulation of the Minister of Energy and Mineral Resources Number 19 of 2008 regarding consumer protection guidelines and procedures on downstream oil and Gas business activities

[20] Asnawi, Habib Soulton. (2016). Penafsiran Mahkamah Konstitusi Terhadap Undang-Undang Minyak dan Gas Bumi. Jurnal Yudisial, Volume 9 No. 3.

[21] Budiato, Agus, Nurmayani, dan Syamsir Syamsu. (2014). Pengawasan Pendistribusian Bahan Bakar Minyak Bersubsidi Provinsi Lampung. Jurnal Ilmiah Hukum Adminsitrasi Negara FH Unila, Volume 1 No. 1.

[22] M, Muslih. (2013). Negara Hukum Indonesia dalam Perspektif Teori Hukum Gustav Radbruch (Tiga Nilai Dasar). Jurnal, Volume IV Nomor 1.

[23] Jessika, Arnelis. (2018). Tinjauan Yuridis dalam Menjatuhkan Pidana terhadap Pelaku Tindak Pidana Pengangkutan Bahan Bakar Minyak Bersubsidi Tanpa Izin yang Sah (Studi Putusan Nomor: 66/Pid.Sus/2017/PN.Kbu). Skripsi. Lampung: Program Sarjana Hukum Universitas Bandar Lampung.

[24] Online. (2019). Pengertian Distribusi, Fungsi, Tujuan, dan Jenis-Jenis Distribusi. Retrieved May 10, 2019 from Diakses pada tanggal 10 Mei 2019 dari https://www.maxmanroe.com/vid/marketing/ pengertian-distribusi.html.

[25] Online. (2019). Alur Pendistribusian Minyak Bumi. Retrieved July 13 from www.bphmigas.go.id. 